\title{
Predation by the scyphomedusan Chrysaora quinquecirrha on Mnemiopsis leidyi ctenophores
}

\author{
Jennifer E. Purcell ${ }^{1, *}$, James H. Cowan $\mathrm{Jr}^{2}$ \\ ${ }^{1}$ Horn Point Environmental Laboratories, PO Box 775, Cambridge, Maryland 21613, USA \\ ${ }^{2}$ University of South Alabama, Dept of Marine Sciences, Mobile, Alabama 36688, USA
}

\begin{abstract}
Numerous species of gelatinous zooplankton are known to eat ctenophores, but their predation interactions have seldom been studied. Laboratory experiments showed that Chrysaora quinquecircha medusae ( 3 to $20 \mathrm{~mm}$ diameter) usually consumed entire ctenophores (Mnemiopsis leidyi) that were equal in diameter or smaller. Although ctenophores larger in diameter than medusae were sometimes consumed completely, often only the lobes of the ctenophores were eaten. These damaged ctenophores healed in the laboratory. Short-lobed ctenophores had reduced fecundity, and probably lowered feeding rates as well. Short-lobed ctenophores were abundant ( 24 to $76 \%$ of the population) in situ during 1990. Large medusae (40 to $120 \mathrm{~mm}$ diameter) in $3.2 \mathrm{~m}^{3}$ in situ mesocosms cleared ctenophores at high rates (up to $6180 \mathrm{l} \mathrm{d}^{-1}$ ). Clearance rates of medusae decreased with increasing ctenophore density and size, and increased with medusa size. The laboratory-determined clearance rate equation, in combination with medusa sizes and densities in situ, predicted that medusae could eliminate ctenophores from a tributary, but not at 2 stations in the main-stem Chesapeake Bay (USA), which was in agreement with in situ population data. The multıple negative effects of $C$. quinquecirrha on $M$. leidyi populations may lead to complex community-level changes that actually may reduce mortality of zooplankton and ichthyoplankton.
\end{abstract}

KEY WORDS: Medusae Jellyfish C Cnidaria Ctenophora Predation Intraguild Clearance rates . Feeding rates Mesocosms

\section{INTRODUCTION}

Many pelagic cnidarians consume other gelatinous species (e.g. reviewed by Purcell 1991b). In fact, other medusae and ctenophores are major components of some medusan diets (Strand \& Hamner 1988, Purcell $1991 \mathrm{a}$, b). However, interactions and predation rates between medusae and gelatinous prey have seldom been studied due to difficulties in working with these large predators and prey in the laboratory and in the field.

Reduction of ctenophore (Mnemiopsis leidyi) populations coincide with the seasonal appearance of the scyphomedusan Chrysaora quinquecirrha in June or July in the tributaries of Chesapeake Bay, USA (Miller 1974, Feigenbaum \& Kelly 1984, Purcell et al. 1991). These medusae feed voraciously on ctenophores in the laboratory (Miller 1974, Larson 1986) and may cause the

•E-mail:purcell@cees.umd.edu ctenophore decline observed in situ. In addition, many of the $M$. leidyi collected in the Choptank River tributary of Chesapeake Bay during August 1990 had one or both lobes greatly reduced from the normal size. We hypothesize that partial predation by $C$. quinquecirrha might cause the short-lobed condition in $M$. leidyi.

Beroe spp. ctenophores are thought to control populations of ctenophores (e.g. Mnemiopsis leidyi, Pleurobrachia spp.) in other locations (Hirota 1974, Kremer \& Nixon 1976, Greve 1981) by swallowing them whole or biting off their lobes (Swanberg 1974). However, Beroe sp. occurs only during September and October in the lower Chesapeake Bay and cannot be responsible for the observed spring decline or short-lobed condition in M. leidyi.

Recent studies to quantify predation by Chrysaora quinquecirrha on zooplankton have emphasized gut content analyses (Purcell 1992, Purcell et al. 1994a, b), yet virtually no ctenophore remains were found in the gut contents. That may have been due to the rapid 
digestion of ctenophores by the medusae (Purcell unpubl.), and/or because the ctenophores mostly disintegrate in formalin (Purcell 1988). Only 9 trials have been previously conducted to estimate predation by $C$. quinquecirrha on Mnemiopsis leidyi (Miller 1974).

In this study, we observed specimens in the laboratory to determine the sizes of ctenophores consumed by medusae and to determine whether partial predation occurred, as suggested from the presence of shortlobed ctenophores in the field. We determined whether starvation or predation caused the shortlobed condition, and compared the fecundity of normal and short-lobed ctenophores. We also measured clearance rates of medusae feeding on ctenophores in $1 \mathrm{~m}^{3}$ laboratory tanks and $3.2 \mathrm{~m}^{3}$ in situ mesocosms, and estimated the percentages of the ctenophore populations that were grazed in situ.

\section{METHODS}

Ctenophores were collected by a fine-mesh dip net from the dock (Choptank River) at the Horn Point Environmental Laboratory (HPEL), Maryland, USA, and transported in buckets to HPEL. Medusae were collected similarly, either at HPEL (1993) or at nearby Ragged Point Marina (1994). Specimens were transferred to $20 \mathrm{l}$ containers filled with $5 \mu \mathrm{m}$ filtered estuary water and used in experiments within $24 \mathrm{~h}$. Specimens were kept and experiments were run at room temperatures $\left(21\right.$ to $\left.23^{\circ} \mathrm{C}\right)$, which is similar to prevailing summertime water temperatures $\left(25\right.$ to $\left.27^{\circ} \mathrm{C}\right)$. Specimens were transferred in spoons or beakers without being removed from water.

Behavioral observations. For observations on specimens $<25 \mathrm{~mm}$ diameter, 1 medusa and 1 ctenophore were placed in 0.1 to 0.51 clear glass beakers with filtered estuary water. The interactions between medusae and ctenophores were observed continuously until ingestion was complete or until the ctenophore was released. Individual large medusae 20 to $65 \mathrm{~mm}$ diameter) were given 5 ctenophores in 20 l clear plastic containers. Submerged ctenophore lengths were measured before and after the trials using a dissecting microscope with an ocular micrometer for specimens $<25 \mathrm{~mm}$ length or a ruler for larger specimens. During the trials, surviving ctenophores were remeasured after several hours. The diameters of medusae placed exumbrella down on a flat surface were measured with a ruler after the trials.

Volumes of larval ctenophores and ephyrae were not measured because of large measurement errors. Because larval ctenophores are spherical, we used the equation for the volume of a sphere to estimate larval volume. We also used Deason's (1982) equation to con- vert length $(\mathrm{mm})$ to wet weight $(\mathrm{g})$ for non-spherical ctenophores. Thus, the approximate volumes for ctenophores 1.7 to $22 \mathrm{~mm}$ length used in this experiment ranged from 0.002 to $2.4 \mathrm{ml}$.

Characterization of short-lobed ctenophores. Ctenophores were collected at 2 stations in the Choptank River in the vicinity of HPEL during August and September 1990. For population data, tows were made at 1 to $2 \mathrm{~m}$ depth using a $1 \mathrm{~m}$ diameter net with a $1.6 \mathrm{~mm}$ soft nylon mesh and a soft, bag-shaped cod end to minimize damage to ctenophores. Specimens for laboratory experiments were collected in jars from the surface. Specimens were transported to HPEL in insulated boxes to maintain ambient temperatures. For all comparisons of short-lobed and normal ctenophores, specimens were judged to have short lobes if the lobes did not extend beyond the auricles, i.e. $\geq 80 \%$ of the lobes were missing, equal to about $25 \%$ of the total body length. Ctenophore volume was determined by displacement of water in a $100 \mathrm{ml}$ graduated cylinder.

To determine whether starvation caused the shortlobed condition, 10 short-lobed and 10 normal ctenophores were kept for $10 \mathrm{~d}$ in $20 \mathrm{l}$ plastic containers filled with $20 \mu \mathrm{m}$ filtered estuary water that was changed daily. The short-lobed group was fed Acartia tonsa copepods twice daily, and the normal group was not fed. After $10 \mathrm{~d}$, the length of their lobes relative to total body size was evaluated visually and volumes measured as above. Initial size measurements were not made to avoid damaging the ctenophores

To determine fecundity, newly collected ctenophores were isolated in $250 \mathrm{ml}$ beakers of water overnight in the dark (15 to $17 \mathrm{~h}$ ), since eggs of Mnemiopsis mccradyi are released in darkness (Martindale 1986). The next morning, volumes of the ctenophores were measured as above, and the number of eggs in each beaker was counted using a dissecting microscope. Fecundity was standardized to ctenophore volume (mi), and compared among short-lobed and normal ctenophores in a Wilcoxon's Signed Ranks Test (paired comparisons).

Clearance rates of medusae feeding on ctenophores. Ctenophores and medusae were collected with dip nets from the docks at HPEL or the Chesapeake Biological Laboratory (CBL), Maryland, and transported in buckets to a $1 \mathrm{~m}^{3}$ indoor tank at HPEL or to $3.2 \mathrm{~m}^{3}$ mesocosms, with $54 \mu \mathrm{m}$ Nitex mesh walls, moored in the mouth of the Patuxent River, Chesapeake Bay, Maryland. The design and handling of the mesocosms is described in Cowan \& Houde (1990). Copepods were added to the $1 \mathrm{~m}^{3}$ tank, which had been filled with $5 \mu \mathrm{m}$ filtered estuary water to promote active behavior of medusae and ctenophores. One medusa and from 3 to 30 ctenophores were released into each container. The containers were left undis- 
turbed for 0.75 to $1 \mathrm{~d}$, after which they were slowly drained through 54 or $64 \mu \mathrm{m}$ mesh to retain medusae and surviving ctenophores. The volume of each ctenophore was measured in a graduated cylinder before and after the experiments. Ctenophore volumes were converted to lengths according to equations in Kremer \& Nixon (1976). Medusa diameter was measured with a ruler after the experiments. The volumes of these medusae were calculated from diameter according to the equation $V=0.00134 D^{242}$, where $V$ is volume (ml) and $D$ is diameter ( $\mathrm{mm}$ ) (Cowan unpubl. results).

Clearance rates (l medusa $\left.{ }^{-1} \mathrm{~d}^{-1}\right)$ were calculated according to the exponential equation $C=\frac{V}{n t} \ln \left(\frac{C_{0}}{C_{t}}\right)$, where $V$ is container volume (1), $n$ is the number of medusae $(=1), t$ is the duration $(\leq 1 \mathrm{~d})$, and $C_{0}$ and $C_{t}$ are the numbers of ctenophores at the beginning and end of the experiment, respectively. Data from experiments in 31 containers using ephyrae and ctenophores $<4 \mathrm{~mm}$ diameter were taken from N. J. Olesen, J. E. Purcell \& D. K. Stoecker (unpubl.).

The resulting clearance rate equation was applied to population data collected in 1987 from 3 locations in Chesapeake Bay: Broad Creek $\left(38^{\circ} 40^{\prime} \mathrm{N}, 76^{\circ} 05^{\prime} \mathrm{W}\right)$, $\operatorname{Stn} 5\left(38^{\circ} 33^{\prime} \mathrm{N}, 76^{\circ} 22^{\prime} \mathrm{W}\right)$, and $\operatorname{Stn} 4\left(38^{\circ} 33^{\prime} \mathrm{N}\right.$, $76^{\circ} 24^{\prime}$ W) (stations as in Purcell et al. 1994b). Densities of Chrysaora quinquecirrha and Mnemiopsis leidyi were measured with a $1 \mathrm{~m}$ diameter, $1.6 \mathrm{~mm}$ mesh net with flowmeter towed at $1 \mathrm{~m}$ depth in Broad Creek (bottom depth $<4 \mathrm{~m}$ ), from 0 to $4 \mathrm{~m}$ at $\operatorname{Stn} 5$ (bottom depth $5 \mathrm{~m}$ ), and from 0 to $11 \mathrm{~m}$ at Stn 4 (bottom depth $20 \mathrm{~m}$, pycno- and oxycline at $11 \mathrm{~m}$ ). Medusae and ctenophores were counted from samples preserved in $5 \%$ formalin, and the preserved sizes converted to live diameter (medusae) and volume (ctenophores), as in Purcell (1992 and 1988, respectively).

\section{RESULTS}

\section{Behavioral observations}

Medusae $\leq 25 \mathrm{~mm}$ diameter completely consumed most ctenophores smaller than themselves $(80.6 \%$ of 36) and some (37.5\% of 32) that were larger (Fig. 1). When the medusa was more than $10 \mathrm{~mm}$ larger than the ctenophore, the length of time between contact and complete ingestion was very short $(4.8 \pm 2.2 \mathrm{~min}$, $\mathrm{n}=6$ ). However, when the size difference was less than $5 \mathrm{~mm}$, ingestion took much longer $(2.5 \pm 1.8 \mathrm{~h}, \mathrm{n}=18)$. Most of the ctenophores equal in size or larger than medusae were only partly consumed $(65.7 \%$ of 35$)$. This partial predation resulted in the removal of one or both lobes of the ctenophore, and sometimes wounds were made along the body. Ephyrae often remained

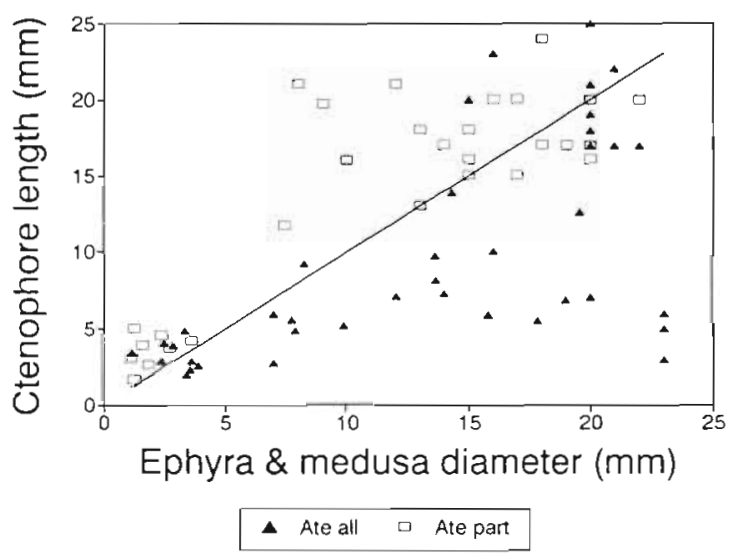

Fig. 1. Chrysaora quinquecirrha. Outcomes of interactions between ephyrae or medusae and ctenophores in the laboratory. Ephyrae and medusae consumed all or part of each ctenophore. The line indicates equal sizes of medusae and ctenophores

attached to larger ctenophores for long periods $(1.8 \pm$ $1.8 \mathrm{~h}, \mathrm{n}=28$ ). Unless most of the body had been eaten, partly-consumed ctenophores healed in 1 to $2 \mathrm{~d}$, and seemed to behave normally. These data indicated that medusae sometimes may consume only the lobes of ctenophores, and that the damaged ctenophores often survive.

\section{Characterization of short-lobed ctenophores}

In the Choptank River where Chrysaora quinquecirrha medusae was the predominant gelatinous species, many of the ctenophores (24 to $76 \%$ ) had short lobes in 1990 (Table 1). On August 8, 1990, the biovolume $\mathrm{m}^{-3}$ of medusae was 136 - and 257 -fold greater than the biovolume $\mathrm{m}^{-3}$ of Mnemiopsis leidyi ctenophores at one location, and 2.4- and 0.2-fold greater at a second location where salinity was lower. On September 5 , medusae were $2.9 \pm 1.6$-fold more numerous than ctenophores ( $\mathrm{n}=4$ tows).

The number of eggs per $\mathrm{ml}$ of ctenophore volume was markedly less for short-lobed ctenophores than for

Table 1. Percentages of normal and short-lobed ctenophores collected in plankton tows in Chesapeake Bay

\begin{tabular}{|lccc|}
\hline $\begin{array}{l}\text { Date } \\
(1990)\end{array}$ & Normal & $\begin{array}{l}\text { Short- } \\
\text { lobed }\end{array}$ & $\begin{array}{c}\text { Total } \\
\text { number }\end{array}$ \\
\hline Aug 8 & 24 & 76 & 165 \\
Aug 14 & 30 & 70 & 137 \\
Aug 16 & 76 & 24 & 45 \\
Aug 24 & 34 & 66 & 129 \\
\hline
\end{tabular}


Table 2. Numbers of eggs (standardized to ctenophore volume) spawned by short-lobed and normal clenophores after collection from the field. Numbers of specimens are in parentheses. All data are means \pm SD

\begin{tabular}{|c|c|c|c|c|}
\hline \multirow{2}{*}{$\begin{array}{l}\text { Date } \\
(1990)\end{array}$} & \multicolumn{2}{|c|}{ Eggs (no. $\mathrm{ml}^{-1}$ ) } & \multicolumn{2}{|c|}{ Ctenophore volume $(\mathrm{ml})$} \\
\hline & Short-lobed & Normal & Short-lobed & Normal \\
\hline Aug 8 & $0.01 \pm 0.03(8)$ & $3.1 \pm 4.6(8)$ & $12.7 \pm 3.2$ & $15.5 \pm 7.0$ \\
\hline Aug 14 & $108.8 \pm 125.8(4)$ & $92.8 \pm 48.5(4)$ & $18.0 \pm 4.8$ & $31.0 \pm 4.9$ \\
\hline Aug 16 & $58.6 \pm 82.2(3)$ & $142.9 \pm 22.5(3)$ & $26.7 \pm 13.5$ & $23.7 \pm 9.3$ \\
\hline Aug 24 & $0.9 \pm 1.6(10)$ & $7.3 \pm 16.7(10)$ & $5.7 \pm 2.3$ & $13.2 \pm 4.1$ \\
\hline Sep 5 & $3.7 \pm 4.5(10)$ & $10.5 \pm 17.4(10)$ & $7.4 \pm 3.0$ & $8.0 \pm 3.9$ \\
\hline
\end{tabular}

Clearance rates of medusae feeding on ctenophores in $3.2 \mathrm{~m}^{3}$ mesocosms decreased significantly with increasing ctenophore densities of 1 to $10 \mathrm{~m}^{-3}$ (Fig. 2A). Similarly, about the same numbers of ctenophores were eaten per day at densities of 5 to $10 \mathrm{~m}^{-3}$. Both results suggest that feeding by medusae was saturated at high ctenophore densities. All ctenophores in a mesocosm were consumed by only 1 medusa among all trials.

normal ctenophores on 4 of 5 sampling dates (Table 2). The overall differences in fecundity were statistically significant $(p<0.05)$, indicating that the fitness of the short-lobed ctenophores was reduced relative to the normal ones.

The lobes of 10 unfed normal ctenophores did not regress during the $10 \mathrm{~d}$ experiment, indicating that starvation does not cause lobe reduction. Ten shortlobed ctenophores that were fed in the laboratory had normal lobes by Day 10 , demonstrating recovery of lobe length in the absence of medusae.

\section{Clearance rates of medusae feeding on ctenophores}

We compared the results of $1 \mathrm{~d}$ predation experiments in a $1 \mathrm{~m}^{3}$ tank and $3.2 \mathrm{~m}^{3}$ mesocosms (Table 3 ). The average ctenophore densities were not significantly lower in the mesocosms $\left(6.3 \mathrm{~m}^{-3}\right)$ than in the tanks $\left(7.4 \mathrm{~m}^{-3}\right)$. Ctenophore sizes were significantly larger in the mesocosms than in the tank (means of 14.1 and $10.5 \mathrm{ml}$ ), but medusa sizes were not significantly different. Estimates of clearance rates (means of 1657 and $702 \mathrm{l}$ medusa $\left.{ }^{-1} \mathrm{~d}^{-1}\right)$ and numbers of ctenophores eaten per day (means of 5.9 and 3.5) were both significantly greater in the mesocosms, indicating reduced feeding in the $1 \mathrm{~m}^{3}$ tank. Therefore, we used data from only the $3.2 \mathrm{~m}^{3}$ mesocosms in further analyses, believing them to be closer to in situ predation rates.
Small ctenophores were cleared at higher rates than large ctenophores by medusae 40 to $109 \mathrm{~mm}$ diameter (Fig. 2B), even though all ctenophores were smaller than the medusae. This and the behavioral observations suggest that large ctenophores may have a refuge from predation. This conclusion is supported further by predation experiments in 201 and $1 \mathrm{~m}^{3}$ tanks, where 69 medusae ( 2 to $120 \mathrm{~mm}$ diam.) were offered a total of 477 ctenophores ( 3 to $95 \mathrm{~mm}$ length). Of the 194 ctenophores eaten, only $3 \%$ were of greater length than the diameter of the medusa that ate them. Of the 283 uneaten ctenophores, $10 \%$ were larger than the medusae.

Clearance rates increased with medusa size, with $3 \mathrm{~mm}$ ephyrae clearing 1.3 to $1.4 \mathrm{l} \mathrm{d}^{-3}$ in $3 \mathrm{l}$ containers (Olesen et al. unpubl.) and medusae 40 to $109 \mathrm{~mm}$ in diameter clearing as much as $6180 \mathrm{l} \mathrm{d}^{-1}$ in $3.2 \mathrm{~m}^{3}$ mesocosms (Fig. 2C). Regression analysis of log transformed data showed that medusa diameter was an important factor: $\mathrm{r}^{2}=0.93, F=685.2, p<1 \times 10^{-14}$, regression equation $\log Y=2.026 \log X-0.756$, where $Y=$ liters cleared medusa ${ }^{-1} \mathrm{~d}^{-1}$, and $X=$ medusa diameter (mm). The above regression includes data on ephyrae from Olesen et al. (unpubl.) because the regression from our data alone underestimated clearance rates for medusae $<30 \mathrm{~mm}$ in diameter. Because ctenophores larger than medusae may not be completely consumed, we believe this equation should be applied only when ctenophore lengths are less than or equal to medusa diameter.

Table 3. Chyrsaora quinquecirrha eating Mnemiopsis leidyi. Comparison of results of predation experiments in $1 \mathrm{~m}^{3}$ tanks and $3.2 \mathrm{~m}^{3}$ mesocosms (1-way ANOVAs). Numbers are means $\pm 1 \mathrm{SD}$. One medusa was used in each container. "Statistically significant

\begin{tabular}{|lcccc|}
\hline & $1 \mathrm{~m}^{3}$ & $3.2 \mathrm{~m}^{3}$ & $F$ & $\mathrm{p}$ \\
\hline No. of experiments & 45 & 48 & - & - \\
Duration (h) & $21.1 \pm 3.0$ & $23.3 \pm 1.25$ & 3.8 & 0.056 \\
Ctenophore density (no. $\left.\mathrm{m}^{-3}\right)$ & $7.4 \pm 2.5$ & $6.3 \pm 3.2$ & 17.6 & $<.0001$. \\
Ctenophore size (ml) & $10.5 \pm 4.4$ & $14.1 \pm 3.8$ & 2.5 & 0.12 \\
Medusa diameter (mm) & $74.7 \pm 21.1$ & $80.7 \pm 15.4$ & 18.8 & $3.7 \times 10^{-5} \cdot$ \\
Medusa clearance $\left(\mathrm{l} \mathrm{cleared}\right.$ ind $\left.^{-1} \mathrm{~d}^{-1}\right)$ & $702.4 \pm 659.1$ & $1657.3 \pm 1331.8$ & 14.3 & $<0.001 \cdot$ \\
Ctenophores eaten (no. $\mathrm{d}^{-1}$ medusa $^{-1}$ ) & $3.5 \pm 3.1$ & $5.9 \pm 3.1$ & & \\
\hline
\end{tabular}



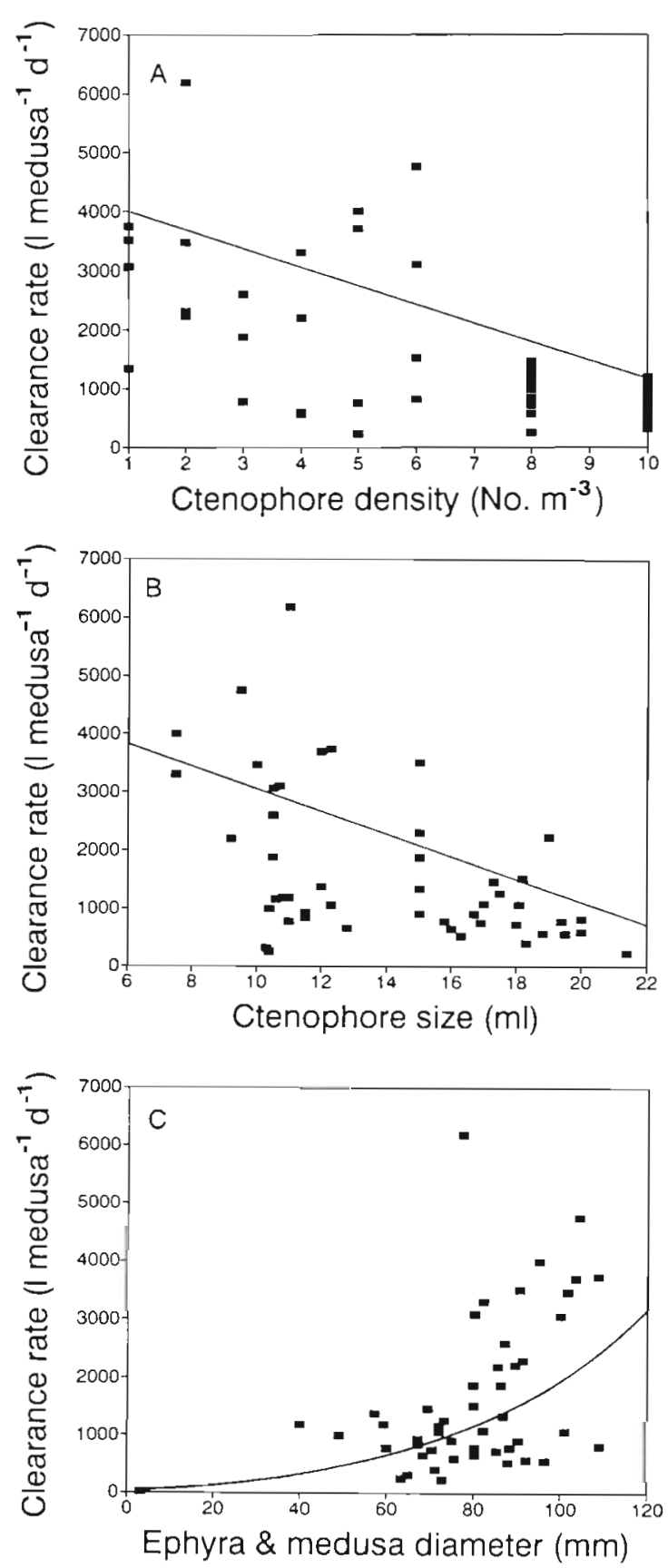

Fig. 2. Chrysaora quinquecirrha. Clearance rates of medusae versus (A) ctenophore density, best fit regression, $Y=$ $-254.5 X+3258.8, r^{2}=0.37, p=5.7 \times 10^{-6} ;(B)$ ctenophore size, best fit regression, $Y=-175.4 X+4124.3, r^{2}=0.25, p=0.0003$; and $(C)$ medusa size, best fit regression, $\log Y=2.026 \log X-$ $0.756 ; \mathrm{r}^{2}=0.93, \mathrm{p}<1 \times 10^{-14}$

We applied the above regression equation for medusa size versus clearance rate to population data from Chesapeake Bay in order to evaluate how our estimates of the predation potentials agreed with population data at 3 sites (Table 4). In the Broad Creek tribu- tary, small ctenophores were abundant $\left(33 \mathrm{~m}^{-3}\right)$ on 15 May, but they had disappeared by 8 June. The calculations indicated that medusae could have cleared 0.6 to $8 \% \mathrm{~d}^{-1}$ of the ctenophores during this period. These estimates of clearance are lower than expected if medusae were the cause of the ctenophore decline; however, the estimates probably are low because some ephyrae may have been extruded through the $1.6 \mathrm{~mm}$ mesh net. The predation potential in Broad Creek increased over time, as medusa size and density increased. During July and August, medusae could have cleared 37 to $210 \% \mathrm{~d}^{-1}$ of the ctenophore population. In September and October, medusa density decreased dramatically, as did the percentages of ctenophores cleared, allowing the ctenophore population to recover in Broad Creek in October $\left(2 \mathrm{~m}^{-3}\right)$.

At the main-stem stations ( 4 and 5) in Chesapeake Bay, medusae were not found on 4 June when ctenophores were small ( 2 to $3 \mathrm{ml}$ equal to 20 to $30 \mathrm{~mm}$, Table 4). When medusae were first sampled on 9 July, they were large but occurred at low densities, and would have cleared only about $4 \% \mathrm{~d}^{-1}$ of the ctenophore population. During August, predation on ctenophores at the main-stem bay stations ( 1 to $60 \% \mathrm{~d}^{-1}$ ) was lower than that in Broad Creek due to lower medusa densities. In addition, on 13 and 20 August, mean ctenophore lengths (about 90 to $100 \mathrm{~mm}$ ) were greater than medusa diameters (32 to $42 \mathrm{~mm}$ ), which could have reduced the actual predation from that calculated. Clearance was always lower at mid-bay $\operatorname{Stn} 4$ than at flank Stn 5, due to lower medusa densities.

\section{DISCUSSION}

\section{Partial predation on ctenophores by medusae}

In our experiments, medusae $(40$ to $120 \mathrm{~mm}$ diameter) completely consumed ctenophores $(2$ to $95 \mathrm{~mm}$ in length) that were smaller than themselves. Ephyrae $(\leq 4 \mathrm{~mm})$ also consumed ctenophores smaller in diameter (Olesen et al. unpubl.). Observations of small specimens $(<25 \mathrm{~mm})$ showed that ctenophores greater in length than medusa in diameter usually were only partly eaten (Fig. 1). This partial predation sometimes produced ctenophores with reduced lobes. Shortlobed ctenophores were numerous in the Choptank River during August 1990. The condition was not due to collection in nets, because jar-collected ctenophores showed the same lobe reduction and because the net tows were short ( $\leq 1 \mathrm{~min}$ ) and gentle ( $1 \mathrm{knot})$. Starvation also did not cause lobe reduction.

No predators other than Chrysaora quinquecirrha known to consume parts of ctenophores were present during our study. The ctenophore Beroe ovata is 
Table 4. Chrysaora quinquecirrha. Clearance rates of medusae feeding on ctenophores calculated from medusa diameter, and the percentages of the ctenophore populations that could be eaten daily (based on medusa clearance rates and densities) in 3 locations in Chesapeake Bay. NP; none present

\begin{tabular}{|c|c|c|c|c|c|c|c|}
\hline Location & Dates (1987) & $\begin{array}{l}\text { Ctenophore } \\
\text { size (ml) }\end{array}$ & $\begin{array}{l}\text { Ctenophores } \\
\left(\text { no. } \mathrm{m}^{-3}\right)\end{array}$ & $\begin{array}{c}\text { Medusa } \\
\text { diameter }(\mathrm{mm})\end{array}$ & $\begin{array}{l}\text { Medusae } \\
\left.\text { (no. } \mathrm{m}^{-3}\right)\end{array}$ & $\begin{array}{l}\text { Medusa } \\
\left(l \text { ind }^{-1} \mathrm{~d}^{-1}\right)\end{array}$ & $\begin{array}{l}=\left(\% d^{-1}\right)\end{array}$ \\
\hline \multirow[t]{6}{*}{ Broad Creek } & May 15 & 2.25 & 33.1 & 10.0 & 0.3 & 18.6 & 0.6 \\
\hline & Jun $8,15,23,30$ & NP & 0 & $16.4 \pm 1.4$ & $50.7 \pm 13.9$ & $50.7 \pm 13.9$ & $22.3 \pm 20.1$ \\
\hline & Jul $8,16,21,28$ & NP & 0 & $22.6 \pm 7.1$ & $8.9 \pm 3.0$ & $102.6 \pm 54.4$ & $98.8 \pm 80.2$ \\
\hline & Aug $4,11,18,25,31$ & NP & 0 & $29.6 \pm 3.2$ & $6.3 \pm 3.0$ & $166.7 \pm 37.2$ & $93.3 \pm 37.9$ \\
\hline & Sep 10,15 & NP & 0 & 36.4 & 0.025 & 253.5 & 0.16 \\
\hline & Oct 13 & 3.1 & 2.4 & 36.8 & 0.02 & 260.6 & 0.5 \\
\hline \multirow[t]{5}{*}{$\operatorname{Stn} 5$} & Jun 4 & 3.2 & 3.4 & NP & 0 & 0 & 0 \\
\hline & Jul 9 & NP & 0 & 33.6 & 0.2 & 216.5 & 4.3 \\
\hline & Aug 6 & 17.6 & 0.1 & 36.1 & 2.4 & 250.3 & 60.1 \\
\hline & Aug 13 & 46.4 & 0.4 & 32.0 & 1.1 & 196.1 & 21.6 \\
\hline & Aug 20 & 63.6 & 0.03 & 34.4 & 1.3 & 227.0 & 29.5 \\
\hline \multirow[t]{5}{*}{$\operatorname{Stn} 4$} & Jun 4 & 2.4 & 4.4 & NP & 0 & 0 & 0 \\
\hline & Jul 9 & 10.8 & 0.05 & 68.4 & 0.04 & 913.3 & 3.6 \\
\hline & Aug 6 & 7.8 & 1.0 & 41.1 & 0.36 & 325.6 & 11.7 \\
\hline & Aug 13 & 51.6 & 2.4 & 32.0 & 0.05 & 196.1 & 1.0 \\
\hline & Aug 20 & 58.4 & 2.0 & 42.8 & 0.22 & 353.4 & 7.8 \\
\hline
\end{tabular}

known to consume whole small lobate ctenophores (Bolinopsis vitrea), but bite off single lobes of large individuals (Swanberg 1974). No Beroe sp. were seen or collected during our sampling in the Choptank River or on 15 to 17 August at 5 stations at the same latitude $\left(38^{\circ} 33^{\prime} \mathrm{N}\right)$ in Chesapeake Bay (Purcell unpubl.). Butterfish Peprilus triacanthus also may partiy consume Mnemiopsis leidyi as they selectively bite anemone parasites from the ctenophores (Oviatt \& Kremer 1977). However, butterfish and harvestfish Peprilus alepidotus, which also consumes ctenophores (Dunnington \& Mansueti 1955), occur infrequently in the low salinity waters of the Choptank River (Hildebrand \& Schroeder 1928). Therefore, interaction with Chrysaora quinquecirrha is the most probable cause of the short-lobed condition in $M$. leidyi.

Reduced fitness of short-lobed ctenophores was demonstrated by lowered fecundity. Eggs and sperm are produced along canals that extend down the lobes, so reduction of the lobes would decrease reproductive area. Less energy would be available for reproduction as well, because the feeding surfaces (lobes) would be smaller, hence prey capture would probably be reduced. Also, energy is required for regeneration of the lobes (Coonfield 1936).

\section{Clearance rates of medusae feeding on ctenophores}

We can compare the clearance rates measured in $3.2 \mathrm{~m}^{3}$ mesocosms with those determined from 9 trials ( 0.15 to $0.25 \mathrm{~d}$ duration) using medusae 5 to $11 \mathrm{~cm}$ in diameter and volumes of ctenophores equal to medusa volumes in $2.4 \mathrm{~m}^{3}$ pools (Miller 1974). His estimated clearance rate of $0.85 \pm 0.16 \mathrm{~m}^{3}$ cleared per $\mathrm{cm}$ medusa diameter per day is much greater than those measured in our study. If we apply his rate to the population data in Table 4, we calculate clearance potentials of 595 to $1700 \% \mathrm{~d}^{-1}$ in Broad Creek during June through August, and means of 230 and $74 \% \mathrm{~d}^{-1}$ in August at Stns 5 and 4, respectively. We conclude that Miller's (1974) rate is too high because ctenophores surely would have been eliminated from Stn 5 and probably from Stn 4 . However, ctenophores were found at both stations in August 1987 (Table 4).

In contrast, the combined data (this study and Olesen et al. unpubl.) used to relate medusa size to clearance rates probably are lower than rates in situ for several reasons. Maximum clearance rates of ephyrae $\leq 4 \mathrm{~mm}$ feeding on ctenophores $<4 \mathrm{~mm}$ diameter in $3 \mathrm{l}$ containers were twice rates in $1 \mathrm{l}$ containers (Olesen et al. unpubl.l. Similarly, clearance rates by medusae $\geq 40 \mathrm{~mm}$ in $3.2 \mathrm{~m}^{3}$ mesocosms were about twice those in $1 \mathrm{~m}^{3}$ tanks (Table 3 ). Reduction of feeding by gelatinous zooplankton in containers has been shown repeatedly (e.g summarized for scyphomedusae in Purcell et al. 1994a). In addition to container effects, some of the clearance rates in both studies were measured at high prey densities ( 5 to $10 \mathrm{~m}^{-3}$ ) and may be low due to saturation of feeding (Fig. 2A). However, densities of ctenophores $\geq 1 \mathrm{~cm}$ long in situ usually are $<5 \mathrm{~m}^{-3}$, and saturation of medusa feeding probably seldom occurs. Finally, upon capture of a large ctenophore, medusae stopped swimming and sank until 
ingestion was complete, which would reduce encounters with subsequent prey.

Several pieces of evidence lead to the conclusion that large ctenophores may be able to avoid or survive predation by medusae: (1) most ctenophores larger than medusae were only partly consumed (Fig, 1); (2) clearance rates decreased with increasing ctenophore (prey) size (Fig. 2B); (3) surviving ctenophores were of larger mean size than consumed ctenophores; and (4) only ctenophores considerably larger than medusae persisted in situ (Table 4). However, we were unable to experimentally evaluate predator-prey interactions throughout the entire size ranges of ctenophores and medusae. Nevertheless, we expect that all ctenophores of lengths less than or equal to medusa diameter could be consumed. In addition, we believe that the regression equation relating medusa size to their clearance of ctenophores overestimates clearance when ctenophores are greater in length than medusa diameter.

From the clearance rate equation, we calculated the percentages of the ctenophore populations consumed in situ, and predicted that medusae would have eliminated ctenophores from a tributary station but not in the main-stem Chesapeake Bay. These predictions are in agreement with ctenophore population data (Purcell et al. 1991, 1994b). Rates predicted for the main-stem bay are lower than in the tributaries because medusae appear later in the main-stem bay and do not reach densities as high as those in the tributaries (Purcell et al. 1994 b). This allows ctenophores to become large in the main-stem bay, where they may escape medusa predation via a size refuge. Effects on Mnemiopsis leidyi populations due to complete consumption by Chrysara quinquecirrha apparently are enhanced by damage to the lobes, which would reduce ctenophore population growth.

Other predators, especially Beroe spp. ctenophores, have been implicated in causing declines in ctenophore populations (Table 5), but generally the evidence has been based on inverse correlations between densities of predators and prey and predation rates have not been measured directly. Only Miller (1974) and Oviatt \& Kremer (1977) previously have estimated predation effects on Mnemiopsis leidyi $\left(50 \% \mathrm{~d}^{-1}\right.$ by Chrysara quinquecirrha and $5 \% \mathrm{~d}^{-1}$ by butterfish). Many other medusae and fishes are known to eat ctenophores (reviewed in Purcell 1991b and Harbison 1993, respectively), but feeding rates or effects on ctenophore populations have not been measured.

Ctenophores probably are extremely important food for Chrysaora quinquecirrha ephyrae and medusae. Clearance rates and growth rates of ephyrae when fed larval ctenophores were greater than when fed ciliates, rotifers, or copepod nauplii (Olesen et al. unpubl.). Consumption of zooplankton and ichthyoplankton in July 1991 (Purcell et al. 1994a) would meet daily nitrogen demands ( $\leq 400 \mu \mathrm{g} \mathrm{N} \mathrm{d}^{-1}$ ) for medusae $\leq 60 \mathrm{~mm}$ diameter (Purcell 1992). However, just 1 ctenophore $23.8 \mathrm{~mm}$ in length ( $3.5 \mathrm{ml}$ volume) contains $400 \mu \mathrm{g}$ nitrogen (calculated from equations in Nemazie et al. 1993). Therefore, ctenophores could contribute more nitrogen than other planktonic foods combined.

Both Chrysaora quinquecirrha and Mnemiopsis leidyi are zooplanktivores and may control summertime zooplankton populations in the tributaries of Chesapeake Bay (Feigenbaum \& Kelly 1984, Purcell 1992). The importance of Mnemiopsis spp. as predators has been evaluated in several studies (reviewed in Kremer 1994). When the ctenophores go unchecked by predation, zooplankton populations can be depleted (e.g. Volovik et al. 1993, Kremer 1994 and references therein). However, the intraguild predation by medusae on ctenophores leads to complex community-level effects that actually may reduce predation on zooplankton and ichthyoplankton populations (Greve 1981, Feigenbaum \& Kelly 1984, Purcell 1991b, Cowan \& Houde 1992). Thus, predation by $C$. quinquecirrha on $M$. leidyi may contribute to the existence of high zooplankton standing stocks and lower ichthyoplankton mortality rates during the summer in Chesapeake Bay (e.g. Cowan \& Houde 1992, Purcell et al. 1994b).

Table 5. Studies that attribute reduction of ctenophore populations to predation

\begin{tabular}{|c|c|c|c|}
\hline Ctenophore species & Predator species & Location & Reference \\
\hline Mnemiopsis leidyi & Chrysaora quinquecirrha & Pamlico River estuary, NC, USA & Miller (1974) \\
\hline M. leidyi & C. quinquecirrha & $\begin{array}{l}\text { Tributaries in southern Chesapeake Bay, } \\
\text { VA, USA }\end{array}$ & Feigenbaum \& Kelly (1984) \\
\hline M. leidyi & C. quinquecirsha & Mid-Chesapeake Bay, MD, USA & Purcell et al. (1994b) \\
\hline M. leidyi & Beroe ovata & York River estuary of Chesapeake Bay, VA & Burrell \& Van Engel (1976) \\
\hline M. leidyi & B. ovata & Narragansett Bay, RI, USA & Kremer \& Nixon (1976) \\
\hline M. leidyi & Peprilus triacanthus & Narragansett Bay, RI, USA & Oviatt \& Kremer (1977) \\
\hline Pleurobrachia pileus & B. gracilis & Wadden Sea, Germany & Greve (1981) \\
\hline P. bachei & Beroe sp. & La Jolla Bight, CA, USA & Hirota $(1974)$ \\
\hline
\end{tabular}


Acknowledgements. We thank F. P Cresswell, D. A Nemazie, $\mathrm{K}$. Cubbage, W. Lo, and C. Morrell for assistance during this study. Funding was provided by NOAA Grant No. NA90AAD-SG063 to the University of Maryland Sea Grant Program. UMCEES contribution no. 2662

\section{LITERATURE CITED}

Burrell VG Jr, Van Engel WA (1976) Predation by and distribution of a ctenophore, Mnemiopsis leidyi A. Agassiz, in the York River esturary. Estuar coast mar Sci 4: $235-242$

Coonfield BR (1936) Regeneration in Mnemiopsis leidyi Agassiz. Biol Bull mar biol Lab, Woods Hole 71:421-428

Cowan JH Jr, Houde ED (1990) Growth and survival of bay anchovy Anchoa mitchill larvae in mesocosm enclosures Mar Ecol Prog Ser 68:47-57

Cowan J.H Jr, Houde ED (1992) Size-dependent predation on marine fish larvae by ctenophores, scyphomedusae, and planktivorous fish. Fish Oceanogr 1:113-126

Deason EE (1982) Mnemiopsis leidyi (Ctenophora) in Narragansett Bay, 1975-79: abundance, size composition, and estimation of grazing. Estuar coast Shelf Sci 15:121-134

Dunnington E, Mansueti R (1955) School of harvestfish feeds on sea walnuts. Maryland Tidewat News 5: $3-4$

Feigenbaum D, Kelly M (1984) Changes in the lower Chesapeake Bay food chain in presence of the sea nettle Chrysaora quinquecirrha (Scyphomedusa). Mar Ecol Prog Ser 19:39-47

Greve W (1981) Invertebrate predator control in a coastal marine ecosystem: the significance of Beroe gracilis (Ctenophora). Kieler Meeresforsch 5:211-217

Harbison GR (1993) The potential of fishes for the control of gelatinous zooplankton. Comm Meet int Coun Explor Sea CM-ICES 1993/L:74

Hildebrand SF, Schroeder WC (1928) Fishes of Chesapeake Bay. Fish Bull US 43:1-388

Hirota J (1974) Quantitative natural history of Pleurobrachia bachei in La Jolla Bight. Fish Bull US 72:295-335

Kremer P (1994) Patterns of abundance for Mnemiopsis in U.S. coastal waters: a comparative overview. ICES J mar Sci 51:347-354

Kremer P, Nixon S (1976) Distribution and abundance of the ctenophore, Mnemiopsis leidyi in Narragansett Bay. Estuar coast mar Sci 4:627-639

Larson RJ (1986) The feeding and growth of the sea nettle, Chrysaora quinquecirrha (Desor), in the laboratory. Estuaries 9:376-379

This article was presented by $R$. J. Conover, Dartmouth, Nova Scotia, Canada
Martindale MQ (1986) The ontogeny and maintenance of adult symmetry properties in the ctenophore Mnemiopsis mccradyi. Devel Biol 118:556-576

Miller RJ (1974) Distribution and biomass of an estuarine ctenophore population, Mnemiopsis leidyi (A. Agassiz) Chesapeake Sci 15:1-8

Nemazie DA, Purcell JE, Glibert PM (1993) Ammonium excretion by gelatinous zooplankton and their contribution to the ammonium requirements of microplankton in Chesapeake Bay. Mar Biol 116:451-458

Oviatt CA, Kremer PM (1977) Predation on the ctenophore, Mnemiopsis leidyi, by butterfish. Peprilus triacanthus, in Narragansett Bay, Rhode Island. Chesapeake Sci 18: $236-240$

Purcell JE (1988) Quantification of Mnemiopsis leidyi (Ctenophora, Lobata) from formalin-preserved plankton samples. Mar Ecol Prog Ser 45:197-200

Purcell JE (1991a) Predation by Aequorea victoria on other species of potentially competing pelagic hydrozoans. Mar Ecol Prog Ser 72:255-260

Purcell JE (1991b) A review of cnidarians and ctenophores feeding on competitors in the plankton. Hydrobiologia 216/217:335-342

Purcell JE (1992) Effects of predation by the scyphomedusan Chrysaora quinquecirrha on zooplankton populations in Chesapeake Bay. Mar Ecol Prog Ser 87:65-76

Purcell JE, Cresswell FP, Cargo DG, Kennedy VS (1991) Differential ingestion and digestion of bivalve larvae by the scyphozoan Chrysaora quinquecirrha and the ctenophore Mnemiopsis leidyi. Biol Bull 180:103-111

Purcell JE, Nemazie DA, Dorsey SE, Houde ED, Gamble JC (1994a) Predation mortality of bay anchovy (Anchoa mitchilli) eggs and larvae due to scyphomedusae and ctenophores in Chesapeake Bay. Mar Ecol Prog Ser 114 $47-58$

Purcell JE, White JR, Roman MR (1994b) Predation by gelatinous zooplankton and resource limitation as potential controls of Acartia tonsa copepod populations in Chesapeake Bay. Limnol Oceanogr 39:263-278

Strand SW, Hamner WM (1988) Predatory behavior of Phacellophora camtschatica and size-selective predation upon Aurelia aurita (Scyphozoa: Cnidaria) in Saanich Inlet, British Columbia. Mar Biol 99:409-414

Swanberg N (1974) The feeding behavior of Beroe ovata. Mar Biol 24:69-76

Volovik SP, Myrzoyan ZA, Volovik GS (1993) Mnemiopsis lesdyi in the Azov Sea: biology, population dynamics, impact to the ecosystem and fisheries. Comm Meet int Coun Explor Sea CM-ICES 1993/L:69

Manuscript first received: February 28, 1995

Revised version accepted: June 28, 1995 